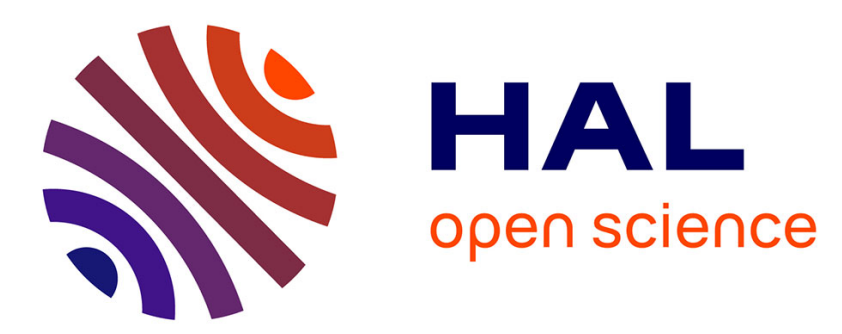

\title{
Prevalence of and factors associated with depression among people living with HIV in France
}

Pascaline Feuillet, France Lert, Laure Tron, Cindy Aubriere, Bruno Spire, Rosemary Dray-Spira

\section{To cite this version:}

Pascaline Feuillet, France Lert, Laure Tron, Cindy Aubriere, Bruno Spire, et al.. Prevalence of and factors associated with depression among people living with HIV in France. HIV Medicine, 2016, 10.1111/hiv.12438 . hal-01376785

\section{HAL Id: hal-01376785 \\ https://hal.sorbonne-universite.fr/hal-01376785}

Submitted on 5 Oct 2016

HAL is a multi-disciplinary open access archive for the deposit and dissemination of scientific research documents, whether they are published or not. The documents may come from teaching and research institutions in France or abroad, or from public or private research centers.
L'archive ouverte pluridisciplinaire HAL, est destinée au dépôt et à la diffusion de documents scientifiques de niveau recherche, publiés ou non, émanant des établissements d'enseignement et de recherche français ou étrangers, des laboratoires publics ou privés. 


\section{Prevalence of and factors associated with depression among HIV-infected people in France}

Running head: Depression among HIV-infected people in France

P. FEUILLET ${ }^{1}$, F. LERT $^{2}$, L. TRON ${ }^{1}$, C. AUBRIERE ${ }^{1}$, B. SPIRE ${ }^{3,4,5}$, R. DRAY-SPIRA ${ }^{1}$ and the ANRS-Vespa2 study group*

${ }^{1}$ Sorbonne Universités, UPMC Univ Paris 06, INSERM, Institut Pierre Louis d'épidémiologie et de Santé Publique (IPLESP UMRS 1136), Équipe de recherche en épidémiologie sociale, Paris, France

2 INSERM, U1018, Center for Research in Epidemiology and Public Health, Department of Epidemiology of Occupational and Social Determinants of Health, Villejuif, France

${ }^{3}$ INSERM, UMR912, Economics and Social Sciences Applied to Health and Analysis of Medical Information (SESSTIM), Marseille, France

${ }^{4}$ Aix Marseille University, UMRS912, IRD, Marseille, France

${ }^{5}$ ORS PACA, Southeastern Health Regional Observatory, Marseille, France

* See Appendix

Correspondence and reprint requests

Pascaline FEUILLET

INSERM, IPLESP UMRS 1136, ERES

Faculté de médecine Saint-Antoine

27, rue Chaligny

75012 Paris FRANCE

E-mail: pascaline.feuillet@gmail.com

\section{Conflicts of interest and source of funding}

The authors have no conflict of interest to disclose. The Vespa2 study was sponsored and funded by the ANRS (Agence Nationale de Recherche sur le Sida et les Hépatites Virales), Paris, France. The funder had no role in the study design, data collection or analysis, the decision to publish, or the preparation of the manuscript. 


\section{ABSTRACT}

Objectives: Depression is common among people living with HIV (PLWHIV) and is associated with poorer therapeutic outcomes and risky behaviours. We sought to estimate the prevalence of major depressive episode (MDE) across PLWHIV groups, to compare it to the general population and to assess its associated factors.

Methods: We used data from the ANRS-Vespa2 study, a national representative sample of PLWHIV conducted in France in 2011. The CIDI-SF was used to characterise the occurrence of an MDE during the previous year. MDE prevalence was assessed among the various groups of PLWHIV and compared to the general population, accounting for the socio-demographic characteristics of the two populations, using multivariate Poisson regression models. The same method was used to assess associated factors.

Results: MDE prevalence was $28.1 \%$ among PLWHIV, ranging from 10.9 to $55.7 \%$ across groups. Compared to the general population by sex regardless of sexual orientation and origin, MDE prevalence was 5.1-fold higher in HIV-infected men who have sex with men (95\%Cl:[3.9-6.6]), 3.1fold higher in non-sub-Saharan African (SSA) heterosexual men (95\%Cl:[2.2-4.4]), 1.6-fold higher in SSA migrant men (95\%Cl:[0.9-2.6]), 2.6-fold higher in non-SSA heterosexual women (95\% Cl:[2.1-3.3]), and 1.9-fold higher in SSA migrant women (95\% $\mathrm{Cl}:[1.5-2.5])$. In the HIV-infected population, MDE was positively related to unemployment, material deprivation, disclosure, experience of discrimination, and untreated hepatitis $\mathrm{C}$, and negatively related to age.

Conclusions: The prevalence of depression varies across the different groups of PLWHIV, with levels much higher than in the general population. Moreover, there is a strong association with socioeconomic status and HIV experience.

Keywords: HIV infection, depression, France 


\section{INTRODUCTION}

In the last few years, the increased efficacy of combined antiretroviral therapies (cARTs) has resulted in a marked reduction in HIV-related morbidities and mortality, and a considerable improvement in the quality of life of people living with HIV (PLWHIV) (1-3). However, this evolving to a chronic condition is associated with increasing non-AIDS-related comorbidities (including psychological morbidities) linked to aging and the burden of disease and treatment $(4,5)$.

In the HIV-infected population, depression is known to be negatively associated with HIV/AIDS treatment adherence, therapeutic outcomes and risky behaviours (6-8), with a potential impact on medical and social outcomes. Consequently, it is important to measure and understand the burden of depression among PLWHIV.

Recently published studies report particularly high levels of depression among PLWHIV worldwide $(4,9-13)$. However, the estimated prevalence is often the overall prevalence. Yet, the HIVinfected population consists of various groups with highly different socioeconomic and behavioural characteristics (14). A number of reports focus on one specific group, most often men who have sex with men (MSM) or intravenous drug users (IDUs) (12), but the comparison of depression among the various groups of PLWHIV has been poorly investigated.

Some studies have reported that the prevalence of depression among PLWHIV is 2 to 3 times higher than in the general population $(13,15)$. However, PLWHIV differ markedly from the general population in terms of their sociodemographic and socioeconomic characteristics that are mostly not taken into account in the comparison. Our objectives were (1) to estimate the prevalence of major depressive episode (MDE) among the various groups of PLWHIV, (2) to compare with the general population, accounting for the specific socioeconomic profile of PLWHIV, and (3) to identify factors associated with MDE. 


\section{METHODS}

\section{Study population}

Data on PLWHIV were obtained from the ANRS-Vespa2 study (VIH: Enquête Sur Les Personnes Atteintes), a national cross-sectional representative survey aimed primarily at assessing the various dimensions of the socioeconomic and health-related characteristics of PLWHIV in France in their diversity $(16,17)$. The study was conducted between April 2011 and January 2012 among PLWHIV aged 18 years or older who had a diagnosis of HIV-infection of at least 6 months' duration and who were either French citizens or immigrants who had been living in France for at least 6 months. They were recruited in 73 hospital departments in France randomly selected from among all the hospital settings delivering HIV care. A total of 5,617 individuals were randomized. Of them, 378 were not solicited and 1,767 declined to participate. Thus, a total of 3022 participants answered a standardised questionnaire administered face-to-face by a trained interviewer. The questionnaire contained detailed questions on sociodemographic characteristics, living conditions, health and healthcare. The data were weighted to account for the sampling design and nonparticipation. Details about the weighting procedure are provided elsewhere $(16,17)$. The survey was approved by the French Advisory Committee on Information Processing in Material Research in the Field of Health and met the ethical requirements of the French National Commission for Computing and Liberties.

Data on the general population were obtained from the 2010 Baromètre Santé, a French national health survey conducted every 5 years by the French Institute for Health Promotion and Health Education (INPES) (18). Data were collected by telephone among a national representative sample of 27,653 noninstitutionalised residents aged 15 to 85 years. The estimated refusal rate was $39 \%$. Questions on depression were administered to a randomly selected subsample of 8,782 participants.

\section{Variables of interest}

\section{Major Depressive Episode}

In both studies, the occurrence of major depressive episode (MDE) during the preceding 12 month period was assessed using the short form of the depression module of the World Health Organization's Composite International Diagnostic Instrument (CIDI-SF) (19). This fully structured instrument is used to diagnose mental disorders according to the definitions and criteria in the International Classification of Diseases (ICD-10) and the Diagnostic and Statistical Manual of Mental Disorders (DSM-IV). A 12-month MDE is defined as a period of at least two weeks with the presence of at least 5 of the 8 core depressive symptoms, and affecting daily activities. MDE was considered to be of severe intensity if the individual reported at least 7 of the 8 depressive symptoms with significant disruption of daily activities. Since hepatitis C treatment provided in 2011 was peginterferon and ribavirin, with a high risk of depression as an adverse effect (20), participants with chronic hepatitis $C$ who were currently on therapy or who had stopped receiving such therapy less than 6 months earlier were excluded from the study. Patients included in the present study were classified as untreated hepatitis $C$ versus no hepatitis $C$.

\section{Covariates}


Data on sociodemographic and socioeconomic characteristics were collected in both studies, including age $(25-34 ; 35-44 ; 45-54 ; 55-65)$, household composition (single; couple with no children; couple with child(ren)), educational attainment (primary level; less than a high school diploma; high school diploma; more than a high school diploma) and occupational status (employed; unemployed; on disability, retired or inactive). Monthly income was categorised in three groups ( $<€ 1100 ; \geq € 1100$ $\leq € 1800$; and $\geq € 1800$ ) based on tertiles.

In addition, the available data on PLWHIV included the following social and health indicator: material deprivation (yes [at least 4 out of 9 privations (food, clothes...)]/no), participation in AIDS association activities during the previous year (yes/no), having experienced discrimination during the previous 2 years (yes, on the basis of HIV; yes, on some other basis; no discrimination), the period of HIV diagnosis (after 2008; between 1997 and 2008; before 1997), being on cART with a viral load <50 copies/mL (yes/no), cancer in the previous 5 years (yes/no), chronic hepatitis B (yes/no), untreated hepatitis C (yes/no [no hepatitis C]) and cardiovascular risk documented from medical records (yes [diabetes, hypertension, cardiovascular disease]/no). For each participant, the proportion of family and friends to whom his/her HIV status had been disclosed was categorised in four groups (none; less than half; more than half; all).

HIV-infected individuals were divided into seven mutually exclusive categories, which correspond to the major groups of PLWHIV in France and which differ markedly in terms of HIV epidemic dynamics and socioeconomic conditions $(14,21)$ : injection drug-using men or women (IDU men/women); men who have sex with men (MSM); sub-Saharan Africa (SSA) migrant men or women; and non-drug-using, non-SSA heterosexual men or women.

\section{Statistical analyses}

The statistical analyses were limited to individuals aged 25 to 65 years for whom information on depression was available and who did not have a current or recent history of hepatitis $C$ therapy at the time of the interview. Individuals with missing information for the variables used in the models were excluded from the analyses.

The first step consisted in determining MDE prevalence and in describing severity overall and by group of PLWHIV.

IDUs were excluded from the remaining analyses because of their very specific susceptibility to depression, regardless of their HIV status $(22,23)$.

MDE prevalence was compared between each group of HIV-infected men or women and the general population of the same gender (but not taking into account sexual orientation and origin). Adjusted prevalence rate ratios (aPRR) were determined using multivariate Poisson regression models with robust variance (24). Each model was adjusted for age, household composition, educational attainment, occupational status and monthly income.

Finally, the factors associated with MDE were assessed in the HIV-positive population using multivariate Poisson regression models with robust variance. The covariates included in the models were sociodemographic and economic characteristics, comorbidities, social relations, and HIVrelated characteristics. Covariates with a $p$-value $<0.10$ in the crude models were included in the multivariate models. To make sure that including all the groups of PLWHIV in the same model did not affect our results, we performed additional analyses stratifying by group that globally lead to the same associated factors for each group (not presented here).

All the analyses were performed using Stata 12 (Stata Corporation, College Station, Texas, USA) and accounted for the data weighting so that the estimates would be representative of the 
entire HIV-infected population followed at hospitals in France in 2011 or of the general population in France in 2010. 


\section{RESULTS}

\section{Demographics of the study population}

Of the 2,392 PLWHIV included in this study, 40\% were MSM, 25\% were SSA migrants (men: $8 \%$; women: $17 \%$ ), $25 \%$ were non-SSA heterosexuals (men: $12 \%$; women: $13 \%$ ) and $10 \%$ were IDUs (men: 6\%; women: 4\%). These groups varied in terms of age (the median age ranging from 39 years among the SSA migrant women to 51 years among the non-SSA heterosexual men) and household composition (the proportion of individuals living as a couple with one or more children ranging from 2.4\% among the MSM to $35.1 \%$ among SSA migrant men) (Table 1). There were also marked differences in terms of educational attainment (the proportion of individuals with more than a high school diploma ranging from $7.8 \%$ among the IDU men to $44 \%$ among the MSM), occupational status (the proportion of unemployed individuals ranging from 6.4\% among the MSM to $24.9 \%$ among the SSA migrant women) and income (the lower quartile of monthly income ranging from $€ 540$ among the SSA migrant women to $€ 1300$ among the MSM).

Among the 5,859 respondents in the general population aged 25 to 65 years, the proportion of men was $49.2 \%$. The median age was 44 years among the men and 45 years among the women. Of the men and women, respectively, $40.1 \%$ and $32.2 \%$ were living as a couple with one or more children. A fourth had more than a high school diploma, and a minority were unemployed (men: 10.8\%; women: 7.5\%). The lower quartile of monthly income among the men was €972 and €900 among the women. Twenty percent of the general population have a chronic disease.

\section{Major depressive episode across the various groups of HIV-infected persons}

Overall, $28.1 \%$ of the HIV-infected participants had experienced a MDE during the previous 12 months. This prevalence of depression varied considerably across the groups of PLWHIV (Figure 1). Among the men, the rate of depression was $32.8 \%$ of the IDUs, $31.3 \%$ in the MSM, $18.3 \%$ in the non-SSA heterosexuals and $10.9 \%$ in the SSA migrants. Among the women, it was $55.7 \%$ in the IDUs, $29.7 \%$ in the non-SSA heterosexuals and $27.0 \%$ in the SSA migrants. Severe MDE was noted for $9.3 \%$ of the HIV-infected individuals. The rate of severe MDE, too, varied significantly across the groups, from $1.6 \%$ in the SSA migrant men to $35.0 \%$ in the IDU women. One third of individuals with MDE had had their first episode prior to HIV diagnosis.

\section{Comparison with the general population}

In the general population, $6.0 \%$ of men and $9.9 \%$ of women had experienced an MDE during the previous 12 months. After adjustment for age, household composition, educational attainment, occupational status and income, the prevalence of MDE remained higher among PLWHIV compared to the general population of the same gender (Table 2). The HIV-infected MSM (aPRR: 5.12, 95\%Cl:[3.94-6.64]; $p=0.000$ ) and HIV-infected non-SSA heterosexual men (aPRR: 3.13, 95\%Cl:[2.21$4.42] ; p=0.000$ ) had a significantly higher prevalence of MDE than men in the general population, but the difference between the HIV-infected SSA migrant men and men in the general population was not significant (aPRR: $1.55,95 \% \mathrm{Cl}:[0.93-2.60] ; p=0.094)$. Among the women, the HIV-infected nonSSA heterosexual women (aPRR: 2.61, 95\%Cl:[2.06-3.32]; $p=0.000$ ) and HIV-infected SSA migrant women (aPRR: $1.94,95 \% \mathrm{Cl}:[1.50-2.50] ; p=0.000$ ) were significantly more likely to have had an MDE than women in the general population. 


\section{Characteristics associated with major depressive episode in the HIV-infected population}

In univariate analysis (Table 3), prevalence varies across PLWHIV groups: the MSM (PRR: 1.71, 95\%Cl:[1.23-2.36]), SSA migrant women (PRR: 1.47, 95\%Cl:[1.05-2.07]) and non-SSA heterosexual women (PRR: 1.62, 95\% Cl:[1.15-2.28]) had a higher prevalence than the non-SSA heterosexual men. MDE prevalence decreased with age; and the participants living as a couple with or without children (vs. living alone) had a lower prevalence (PRR: 0.70, 95\%Cl:[0.52-0.94] / PRR: $0.71,95 \% \mathrm{Cl}:[0.57-0.89])$. As regards socioeconomic factors, those unemployed (vs. employed) (PRR: 1.81, 95\%Cl:[1.46-2.24]), on disability, retired or inactive (PRR: $1.30,95 \% \mathrm{Cl}:[1.08-1.57]$ ) or with material deprivation (PRR: 1.84, 95\%Cl:[1.54-2.20]) were more likely to have MDE. The social relations factors were also significantly associated with a higher prevalence of MDE: disclosure within the friend and family network (more than half vs. less than half, PRR: 1.50, 95\%Cl:[1.24-1.81] / all, PRR: 1.78, 95\%Cl:[1.42-2.23]); participation in AIDS association activities (PRR: 1.29, 95\%Cl:[1.051.59]); and discrimination on the basis of HIV status (PRR: $2.29,95 \% \mathrm{Cl}:[1.86-2.81]$ ) or on some other basis (PRR: $1.82,95 \% \mathrm{Cl}:[1.49$ to 2.22]). As for comorbidities, the individuals with untreated hepatitis $\mathrm{C}$ had a higher prevalence of MDE (PRR: 1.59, 95\% Cl:[1.14-2.22]). Finally, being HIV-diagnosed for a longer period was related to a lower prevalence of MDE (1997-2008 vs. $\geq 2009$, PRR: 0.67, 95\%Cl:[0.51-0.89] / <1997 vs. $\geq 2009$, PRR: 0.75, 95\%Cl:[0.57-0.99]), as was being on treatment success (vs. untreated/VL>50copies, PRR: 0.79, 95\%Cl:[0.63-0.99]).

In the final multivariate model (Table 3), MDE prevalence always decreased with age. The prevalence among the MSM was 1.52 times higher than in the non-SSA heterosexual men (95\%Cl:[1.07-2.16]), and it was 2.08 times lower among the SSA migrant men (aPRR: 0.48, 95\%Cl:[0.27-0.83]). In addition, those unemployed (vs. employed) (aPRR: 1.43, 95\%Cl:[1.15-1.77]) or with material deprivation (aPRR: 1.69, 95\%Cl:[1.41-2.03]) were more likely to have MDE. Regarding the social relations factors, disclosure within the friend and family network (more than half vs. less than half, aPRR: 1.27, 95\%Cl:[1.05-1.54] / all, aPRR: 1.50, 95\%Cl:[1.17-1.92]) and discrimination on the basis of HIV status (aPRR: 1.75, 95\%Cl:[1.41-2.18]) or on some other basis (aPRR: 1.74, 95\%Cl:[1.45-2.09]; $p=0.000)$ were associated with a higher prevalence of MDE. The prevalence was also higher among those with untreated hepatitis C (aPRR: 1.60, 95\%Cl:[1.16-2.20]). 


\section{DISCUSSION}

Our results indicate that, in France, almost 3 in $10 \mathrm{HIV}$-infected people had experienced an MDE in the previous 12-month period. The prevalence of MDE varied from 10.9 to $55.7 \%$ across the various groups of PLWHIV. Compared to the general population of the same gender, HIV-infected men had a 1.55- to 5.12-fold higher prevalence, and HIV-infected women had a 1.94- to 2.61-fold higher prevalence. In the HIV-infected population, the prevalence of MDE negatively related to age and appeared to be positively related to unemployment, material deprivation, disclosure, experience of discrimination and having untreated hepatitis $C$.

The use of the CIDI-SF constitutes a major strength of our study. It is a widely validated and widely used diagnostic test for depression in international studies (25-28), including HIV studies (2931). The CIDI-SF is convergent with the full-length CIDI (19). There are many different depression scales, which often makes it difficult to compare data between studies, but the CIDI-SF was used as a tool for measuring depression both in the ANRS-Vespa2 study and the 2010 Baromètre Santé survey, with the result that a comparison was possible. Of note, data were collected face-to-face among HIVinfected people versus by phone in the general population. However, we did not find any evidence suggesting that the mode of administration leads to different responses to the CIDI-SF questionnaire. Another significant strength is the nationally representative nature of the ANRS-Vespa2 dataset, as well as the availability of detailed sociodemographic, economic and HIV-related information. However, it should be noted that the study was limited to HIV-infected persons attending hospitals for HIV care. Presently, in France, HIV care is essentially provided at hospitals, and since 2006, the experts have been recommending that all PLWHIV have at least an annual checkup at a hospital (32). Estimates are therefore likely to apply to the vast majority of PLWHIV being treated in France. Yet, since the ANRS-Vespa2 study was cross-sectional, our findings describe MDE during the previous 12 months and only the year of first episode to account for the individual depression history. The prevalence of MDE among HIV-infected individuals is consistent with recent European studies (33, 34). The higher prevalence of MDE than in the general population is also consistent with the few reports in which such a comparison is made. A meta-analysis found a 2-fold higher frequency of MDE in seropositive individuals than in seronegative individuals (13), although it did not take the specific socioeconomic profile of PLWHIV into account. In the United States, HIV-infected persons were recently found to have a 3-fold higher prevalence of depression than the general population (15) when gender and, in turn, age, race/ethnicity and education were controlled for. But when controlled for gender and annual household income, the prevalence was 1.5-fold higher, which indicates that the difference in income between the two populations played an important role. In our study, the comparison accounted simultaneously for the specificities of the PLWHIV, with controlling for monthly income not reducing the prevalence rate ratio. The difference between the HIV-infected population and the general population is much wider than differences observed within the general population, for instance for the materially deprived versus the well-off (35), or the difference between people with cancer versus those without cancer (36).

In this study, each socioepidemiological group of PLWHIV was considered separately. IDU men and women had the highest prevalence of MDE of all the groups, as reported in recent reviews $(12,37)$. MSM were also a high-risk group for depression in the HIV-infected population in our study, as well as in previous reports $(12,37)$. Considering the low proportion of MSM in the general population ( $0.4 \%$ as it is defined by male-to-male sex in the last 12 months), the comparison was 
made with the entire male population. MSM are known to be at high risk for psychological disorders compared to the rest of the population. A meta-analysis revealed a 1.5-fold higher risk of depression and anxiety disorders, and a 2 -fold higher risk of suicide attempts (38). Therefore, our prevalence rate ratio probably reflects differences in HIV serostatus but also between MSM and heterosexuals. Conversely, HIV-infected SSA migrant men and women tended to be less depressed than other groups of men and women. However, the rate of depression was higher among the HIV-infected SSA migrants in our study than those reported among HIV-infected populations in sub-Saharan Africa (39, 40). This is consistent with studies that reported higher rates of depression among migrants than among the population in their country of origin (41). Compared to the general population of the same gender, the prevalence of depression is higher among SSA migrant women but not significantly so among SSA migrant men. Women could be affected more than men because they are more isolated, less educated and more deprived (42), as observed in the ANRS-Vespa2 study. Considering the low proportion of SSA migrants in the general population ( $0.6 \%$ in the Baromètre Santé sample), the population of reference actually consisted mostly of non-SSA heterosexuals. Some studies have reported a slightly higher lifetime prevalence of depression in the entire migrant population than in the general population (41). Therefore, our prevalence rate ratio probably reflects differences in HIV serostatus but also between migrants and non-migrants. In addition, the cross-cultural validity of the French version of the CIDI-SF among migrant subgroups might be questioned.

Our findings indicate a higher prevalence of MDE among seropositive women than seropositive men, which is consistent with recent reviews $(9,10,12,43)$. Other characteristics, such as age, employment status and level of income, are commonly associated with depression among $\operatorname{PLWHIV}(9,10,12,15)$ and were also observed in this study. In the general population of most countries, there is also a high correlation with sex, age, marital status, employment status and level of income $(44,45)$. Therefore, sociodemographic and economic characteristics related to depression are similar in both populations. However, the adjusted prevalence rate of depression is higher among PLWHIV than in the general population, the hypothesis being that HIV disease plays a role. For instance, discrimination is known to be frequent and persistent against PLWHIV (46). Our results indicate a positive association between MDE and experience of discrimination, regardless of the perceived reason. The disclosure of HIV status is another important concern. The more PLWHIV informed their close relatives (family and friends), the higher the prevalence of MDE, suggesting two possible interpretations: disclosure needed to seek support to cope with depression or disclosure contributing to depression due to negative attitudes and discrimination. However data are lacking to disentangle these assumptions. However, due to the cross-sectional design of our study, disclosure status before the onset of MDE was not known. A recent German study reported no association between PLWHIV's mental health status and disclosure or experienced social support (47). Finally, the association between having depression and untreated hepatitis $C$ needs to be considered with caution but is a clue that hepatits $\mathrm{C}$ is a marker of vulnerability. More generally, there is no possible causal interpretation between MDE and the characteristics of HIV-infected individuals (9). On the one hand, people with mental disorders, such as MDE, would have an increased risk of exposure to HIV infection. On the other hand, several HIV-related psychosocial or biological factors could lead to the development of depression, such as stigma or a persistent viral presence in the central nervous system.

In conclusion, the results of this study show that, despite the major improvements in HIV care and treatment, the prevalence of depression remains much higher in the HIV-infected 
population than in the general population. Moreover, depression rates vary across the groups of PLWHIV and are strongly related to socioeconomic status and enduring discrimination. 


\section{ACKNOWLEDGEMENTS}

The authors are deeply grateful to the people living with HIV who agreed to participate in the ANRS-Vespa2 study and to all the investigators at the participating hospitals.

They also thank Yann Le Strat (InVS, Saint-Maurice), Lise Cuzin (Hôpital Purpan, Toulouse) and Laurence Meyer (INSERM, UMRS1018, Le Kremlin Bicêtre) for their methodological support, and the community-based organisations AIDES and Act-Up Paris for their ground support for implementing the ANRS-Vespa2 study.

The authors also thank the French Institute for Health Promotion and Health Education (INPES) for providing data from the 2010 Baromètre Santé survey.

The Vespa2 study was sponsored and funded by the ANRS (Agence Nationale de Recherche sur le Sida et les Hépatites Virales), Paris, France.

P.F., R.D.-S., F.L., L.T., C.A., B.S. and ANRSVSG conceived and designed the experiments. P.F. performed the statistical analyses. P.F., R.D.-S. and F.L. analysed the data and wrote the manuscript. L.T., C.A. and B.S. critically reviewed the manuscript. 


\section{REFERENCES}

1. Smith CJ, Ryom L, Weber R, et al. Trends in underlying causes of death in people with HIV from 1999 to 2011 (D:A:D): a multicohort collaboration. Lancet. 2014;384:241-8.

2. Douab T, Marcellin F, Vilotitch A, et al. Health-related quality of life of people living with HIV followed up in hospitals in France: comparing trends and correlates between 2003 and 2011 (ANRSVESPA and VESPA2 national surveys). AIDS Care. 2014;26 Suppl 1:S29-40.

3. Samji H, Cescon A, Hogg RS, et al. Closing the gap: increases in life expectancy among treated HIV-positive individuals in the United States and Canada. PLoS One. 2013;8:e81355.

4. Hasse $B$, Ledergerber $B$, Furrer $\mathrm{H}$, et al. Morbidity and aging in HIV-infected persons: the Swiss HIV cohort study. Clin Infect Dis. 2011;53:1130-9.

5. Mocroft A, Reiss P, Gasiorowski J, et al. Serious fatal and nonfatal non-AIDS-defining illnesses in Europe. J Acquir Immune Defic Syndr. 2010;55:262-70.

6. Sin NL and DiMatteo MR. Depression treatment enhances adherence to antiretroviral therapy: a meta-analysis. Ann Behav Med. 2014;47:259-69.

7. Gonzalez JS, Batchelder AW, Psaros C and Safren SA. Depression and HIV/AIDS treatment nonadherence: a review and meta-analysis. J Acquir Immune Defic Syndr. 2011;58:181-7.

8. Hartzell JD, Janke IE and Weintrob AC. Impact of depression on HIV outcomes in the HAART era. J Antimicrob Chemother. 2008;62:246-55.

9. Nanni MG, Caruso R, Mitchell AJ, Meggiolaro E and Grassi L. Depression in HIV Infected Patients: a Review. Current Psychiatry Reports. 2014;17.

10. Eller LS, Rivero-Mendez M, Voss J, et al. Depressive symptoms, self-esteem, HIV symptom management self-efficacy and self-compassion in people living with HIV. AIDS Care. 2013;26:795-803.

11. Sherr L, Clucas C, Harding R, Sibley E and Catalan J. HIV and depression--a systematic review of interventions. Psychol Health Med. 2011;16:493-527.

12. Rabkin JG. HIV and depression: 2008 review and update. Curr HIV/AIDS Rep. 2008;5:163-71.

13. Ciesla JA and Roberts JE. Meta-analysis of the relationship between HIV infection and risk for depressive disorders. Am J Psychiatry. 2001;158:725-30.

14. Lert $F$, Annequin $M$, Tron $L$, et al. Socioeconomic conditions of people living with HIV followed at hospital in metropolitan France. Results of the ANRS-VESPA2 study. Bull Epidémiol Hebd. 2013;26-27:293-9.

15. Do AN, Rosenberg ES, Sullivan PS, et al. Excess burden of depression among HIV-infected persons receiving medical care in the united states: data from the medical monitoring project and the behavioral risk factor surveillance system. PLoS One. 2014;9:e92842.

16. Tron L, Lert F, Spire B and Dray-Spira R. Tobacco smoking in HIV-infected versus general population in france: heterogeneity across the various groups of people living with HIV. PLoS One. 2014;9.

17. Dray-Spira R, Spire B, Lert F and Vespa2 g. General Method of the ANRS-VESPA2 Study. Bull Epidemiol Hebd. 2013;26-27:321-4.

18. Beck F, Gautier A, Guignard R and Richard J-B. Health Barometer 2010 Methods. coll Baromètres santé. Saint-Denis, French Institute for Health Prevention and Health Education (Inpes), 2013.

19. Kessler RC, Andrews G, Mroczek D, Ustun B and Wittchen HU. The World Health Organization composite international diagnostic interview short-form (CIDI-SF). International journal of methods in psychiatric research. 1998;7:171-85.

20. Udina M, Castellvi P, Moreno-Espana J, et al. Interferon-induced depression in chronic hepatitis C: a systematic review and meta-analysis. J Clin Psychiatry. 2012;73:1128-38.

21. Dray-Spira R, Wilson d'Almeida K, Aubrière C, et al. Health status of people living with HIV followed at hospital in metropolitan France in 2011 and characteristics of those recently diagnosed. Results of the ANRS-Vespa2 study. Bull Epidémiol Hebd. 2013;26-27:285-92.

22. Jones DL, Waldrop-Valverde D, Gonzalez P, et al. Mental health in HIV seronegative and seropositive IDUs in South Florida. AIDS Care. 2009;22:152-8. 
23. Knowlton AR, Latkin CA, Chung S, Hoover DR, Ensminger $M$ and Celentano DD. HIV and depressive symptoms among low-income illicit drug users. AIDS Behav. 2000;4:353-60.

24. Barros AJ and Hirakata VN. Alternatives for logistic regression in cross-sectional studies: an empirical comparison of models that directly estimate the prevalence ratio. BMC Med Res Methodol. 2003;3:21.

25. Bulloch A, Lavorato D, Williams J and Patten S. Alcohol consumption and major depression in the general population: the critical importance of dependence. Depress Anxiety. 2012;29:1058-64.

26. Pez $\mathrm{O}$, Gilbert $\mathrm{F}$, Bitfoi $\mathrm{A}$, et al. Validity across translations of short survey psychiatric diagnostic instruments: CIDI-SF and CIS-R versus SCID-I/NP in four European countries. Soc Psychiatry Psychiatr Epidemiol. 2009;45:1149-59.

27. Wang J, Hausermann M, Ajdacic-Gross V, Aggleton $P$ and Weiss MG. High prevalence of mental disorders and comorbidity in the Geneva Gay Men's Health Study. Soc Psychiatry Psychiatr Epidemiol. 2007;42:414-20.

28. Egede LE and Zheng D. Independent factors associated with major depressive disorder in a national sample of individuals with diabetes. Diabetes Care. 2003;26:104-11.

29. Ingersoll KS and Heckman CJ. Patient-clinician relationships and treatment system effects on HIV medication adherence. AIDS Behav. 2005;9:89-101.

30. Asch SM, Kilbourne AM, Gifford AL, et al. Underdiagnosis of depression in HIV: who are we missing? J Gen Intern Med. 2003;18:450-60.

31. Sherbourne CD, Hays RD, Fleishman JA, et al. Impact of psychiatric conditions on healthrelated quality of life in persons with HIV infection. Am J Psychiatry. 2000;157:248-54.

32. Morlat P. Medical care of people living with HIV. Guidelines of the experts group. 2013 Report [in French]. La documentation française. Paris, 2013.

33. Pineau S, Cariou Y, Supiot $C$, et al. Evaluation des troubles dépressifs dans une cohorte de patients adultes vivant avec le VIH (PVVIH) suivis dans les centres du COREVIH Pays de Loire. 16th National SFLS Congress. Nantes, France, 2015.

34. Anagnostopoulos A, Ledergerber B, Jaccard R, et al. Frequency of and Risk Factors for Depression among Participants in the Swiss HIV Cohort Study (SHCS). PLoS One. 2015;10:e0140943.

35. Lorant V, Deliege D, Eaton W, Robert A, Philippot P and Ansseau M. Socioeconomic inequalities in depression: a meta-analysis. Am J Epidemiol. 2003;157:98-112.

36. Beck F, Guilbert $P$ and Gautier Ad. Baromètre santé 2005 Attitudes et comportements de santé. coll. Baromètres santé. Saint-Denis, INPES, 2007: 608 p.

37. Penzak SR, Reddy YS and Grimsley SR. Depression in patients with HIV infection. Am J Health Syst Pharm. 2000;57:376-86;quiz 87-9.

38. King $M$, Semlyen J, Tai SS, et al. A systematic review of mental disorder, suicide, and deliberate self harm in lesbian, gay and bisexual people. BMC Psychiatry. 2008;8:70.

39. Belenky NM, Cole SR, Pence BW, Itemba D, Maro V and Whetten K. Depressive symptoms, HIV medication adherence, and HIV clinical outcomes in Tanzania: a prospective, observational study. PLoS One. 2014;9:e95469.

40. Gaynes BN, Pence BW, Atashili J, O'Donnell J, Kats D and Ndumbe PM. Prevalence and predictors of major depression in HIV-infected patients on antiretroviral therapy in Bamenda, a semiurban center in Cameroon. PLoS One. 2012;7:e41699.

41. Fenta H, Hyman I and Noh S. Determinants of depression among Ethiopian immigrants and refugees in Toronto. J Nerv Ment Dis. 2004;192:363-72.

42. Wong JP. Intersecting sexuality, gender, race, \& citizenship: mental health issues faced by immigrants \& refugees living with HIV/AIDS. Toronto, ON, 2004.

43. Robertson K, Bayon C, Molina JM, et al. Screening for neurocognitive impairment, depression, and anxiety in HIV-infected patients in Western Europe and Canada. AIDS Care. 2014;26:1555-61.

44. Kessler RC and Bromet EJ. The epidemiology of depression across cultures. Annu Rev Public Health. 2013;34:119-38. 
45. Chan Chee C, Beck F, Sapinho D and Guilbert P. Depression in France. Anadep 2005 study. coll. Etudes santé. Saint-Denis, INPES, 2009: 208.

46. Marsicano E, Dray-Spira R, Lert F, Aubriere C, Spire B and Hamelin C. Multiple discriminations experienced by people living with HIV in France: results from the ANRS-Vespa2 study. AIDS Care. 2014;26 Suppl 1:S97-S106.

47. Kittner JM, Brokamp F, Thomaidis T, et al. Disclosure and Experienced Social Support are not Related to Anxiety or Depression in a German HIV Patient Cohort. Infect Chemother. 2014;46:77-83. 


\section{TABLES AND FIGURES}

Table 1. Sociodemographic and socioeconomic characteristics of people living with HIV and the general population in France.

\begin{tabular}{|c|c|c|c|c|c|c|c|c|c|}
\hline & \multicolumn{5}{|l|}{ MEN } & \multicolumn{4}{|l|}{ WOMEN } \\
\hline & \multirow{2}{*}{$\begin{array}{l}\text { GENERAL } \\
\text { POPULATION } \\
\text { All men (\%) }\end{array}$} & \multicolumn{4}{|l|}{ PLWHIV } & \multirow{2}{*}{$\begin{array}{l}\text { GENERAL } \\
\text { POPULATION } \\
\\
\text { All women (\%) }\end{array}$} & \multicolumn{3}{|l|}{ PLWHIV } \\
\hline & & MSM (\%) & $\begin{array}{l}\text { Migrants } \\
\text { from SSA (\%) }\end{array}$ & $\begin{array}{l}\text { Non-SSA } \\
\text { heterosexuals } \\
(\%)\end{array}$ & $\begin{array}{l}\text { IDUs } \\
(\%)\end{array}$ & & $\begin{array}{l}\text { Migrants } \\
\text { from SSA (\%) }\end{array}$ & $\begin{array}{l}\text { Non-SSA } \\
\text { heterosexuals } \\
\text { (\%) }\end{array}$ & IDUs (\%) \\
\hline & $(\mathrm{N}=2,613)$ & $(\mathrm{N}=1,078)$ & $(\mathrm{N}=141)$ & $(\mathrm{N}=276)$ & $(N=140)$ & $(N=3,246)$ & $(\mathrm{N}=353)$ & $(\mathrm{N}=312)$ & $(\mathrm{N}=92)$ \\
\hline \multicolumn{10}{|l|}{ Age at time of survey } \\
\hline $25-34$ & 22.8 & 9.7 & 13.5 & 4.4 & 0.4 & 23.2 & 29.5 & 9.4 & 7.7 \\
\hline $35-44$ & 27.4 & 25.7 & 26.1 & 21.2 & 12.5 & 26.5 & 46.6 & 27.6 & 16.6 \\
\hline $45-54$ & 25.6 & 42.1 & 43.7 & 35.4 & 79.4 & 26.2 & 16.7 & 40.0 & 65.8 \\
\hline $55-65$ & 24.2 & 22.4 & 16.7 & 39.0 & 7.7 & 24.2 & 7.2 & 23.0 & 9.9 \\
\hline \multicolumn{10}{|l|}{ Household composition } \\
\hline No partner & 26.2 & 64.6 & 49.2 & 47.7 & 57.6 & 28.5 & 61.6 & 57.8 & 58.8 \\
\hline Couple without children & 33.7 & 33.0 & 15.8 & 35.4 & 23.6 & 32.2 & 9.1 & 27.5 & 30.9 \\
\hline Couple with child(ren) & 40.1 & 2.4 & 35.1 & 16.9 & 18.8 & 39.4 & 29.3 & 14.8 & 10.4 \\
\hline \multicolumn{10}{|l|}{ Educational attainment } \\
\hline Primary level & 14.8 & 6.0 & 19.2 & 14.2 & 20.4 & 16.3 & 24.2 & 15.0 & 27.6 \\
\hline Less than a high school diploma & 43.8 & 31.7 & 24.0 & 45.5 & 66.4 & 37.5 & 46.6 & 40.1 & 40.4 \\
\hline High school diploma & 15.6 & 18.2 & 17.8 & 11.3 & 5.4 & 17.9 & 17.9 & 16.3 & 16.7 \\
\hline More than a high school diploma & 25.8 & 44.0 & 39.0 & 29.0 & 7.8 & 28.3 & 11.4 & 28.6 & 15.2 \\
\hline \multicolumn{10}{|l|}{ Occupational status } \\
\hline Employed & 71.6 & 64.8 & 63.2 & 52.5 & 36.7 & 63.1 & 54.5 & 52.3 & 21.7 \\
\hline Unemployed & 10.8 & 6.4 & 23.8 & 7.7 & 9.1 & 7.5 & 24.9 & 8.8 & 10.5 \\
\hline On disability, retired or inactive & 17.8 & 28.8 & 12.9 & 39.8 & 54.2 & 29.4 & 20.6 & 38.9 & 67.7 \\
\hline \multicolumn{10}{|l|}{ Monthly income } \\
\hline$<€ 1100$ & 28.4 & 18.3 & 61.5 & 28.6 & 59.0 & 35.9 & 71.0 & 40.5 & 54.5 \\
\hline$\geq € 1100-<€ 1800$ & 39.4 & 25.3 & 30.3 & 33.1 & 25.2 & 36.6 & 24.0 & 30.3 & 38.4 \\
\hline$\geq € 1800$ & 32.3 & 56.4 & 8.2 & 38.4 & 15.9 & 27.4 & 5.1 & 29.2 & 7.1 \\
\hline
\end{tabular}

MSM: Men who have sex with men, SSA: Sub-Saharan Africa 
Figure 1. Prevalence of major depressive episode among people living with HIV.

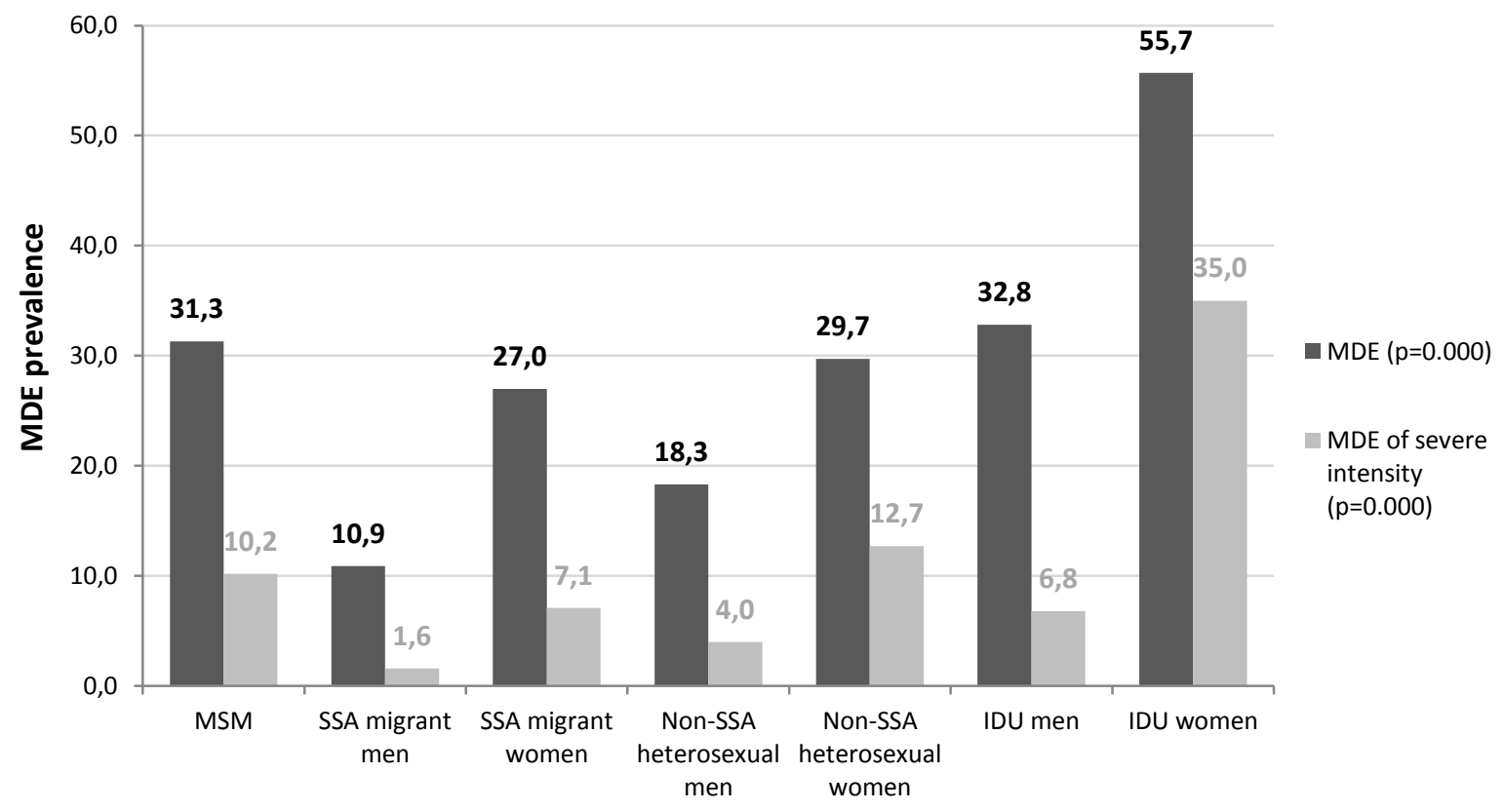

MDE: Major depressive episode; MSM: Men who have sex with men; SSA: Sub-Saharan Africa. 
Table 2. Prevalence rate ratios of major depressive episode in men and women living with HIV as compared to the French general population of the same gender.

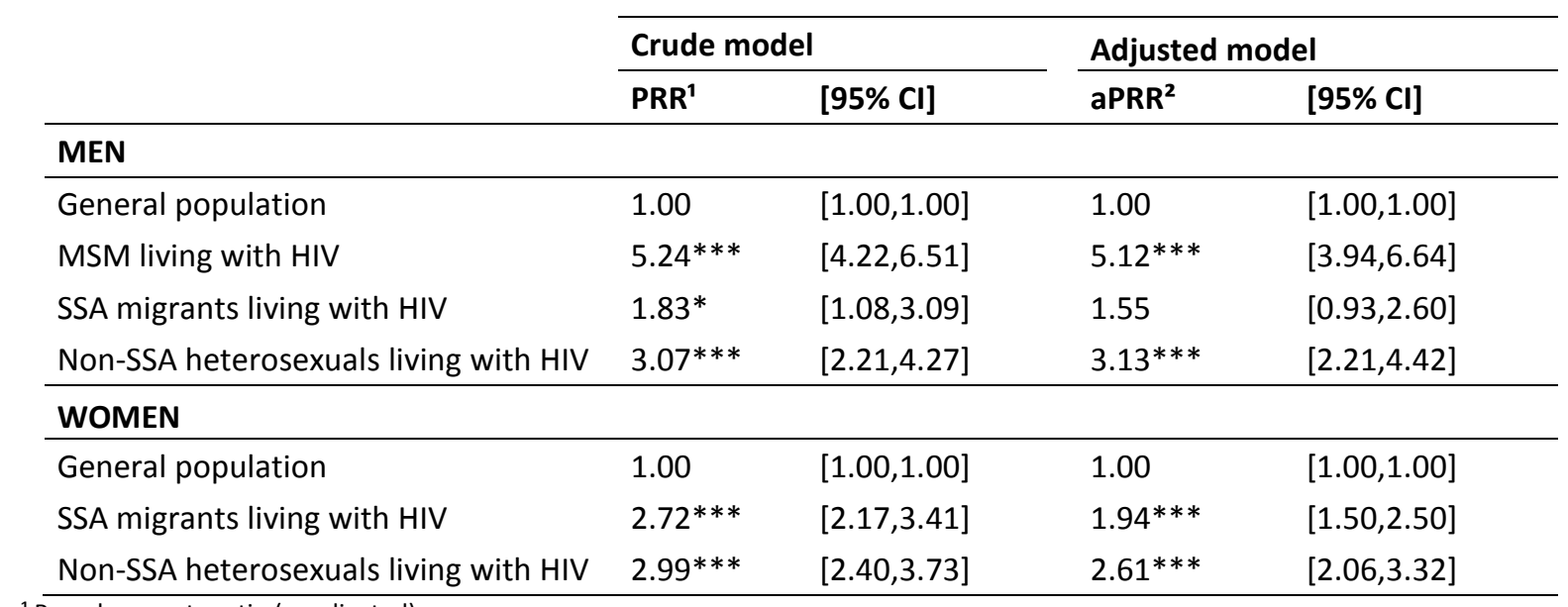

1 Prevalence rate ratio (unadjusted).

${ }^{2}$ Prevalence rate ratio adjusted for age, household composition, educational attainment, occupational status and income.

Significance level: $* * * p<0.001, * * p<0.01, * p<0.05 . \mathrm{Cl}=$ Confidence interval.

MSM: Men who have sex with men; SSA: Sub-Saharan Africa. 
Table 3. Factors associated with major depressive episode in people living with HIV.

\begin{tabular}{|c|c|c|c|c|c|}
\hline & \multirow{3}{*}{$\begin{array}{l}\mathbf{N} \text { (\% with } \\
\text { MDE) }\end{array}$} & \multirow{2}{*}{\multicolumn{2}{|c|}{ Crude model }} & \multirow{2}{*}{\multicolumn{2}{|c|}{ Adjusted model }} \\
\hline & & & & & \\
\hline & & PRR $^{1}$ & {$[95 \% \mathrm{Cl}]$} & aPRR $^{2}$ & {$[95 \% \mathrm{Cl}]$} \\
\hline Total & $2,160(26.6)$ & & & & \\
\hline \multicolumn{6}{|l|}{ Sociodemographic variables } \\
\hline \multicolumn{6}{|l|}{ Socioepidemiological group } \\
\hline MSM & $1,078(31.3)$ & $1.71 * *$ & {$[1.23,2.36]$} & $1.52^{*}$ & {$[1.07,2.16]$} \\
\hline SSA migrant men & $141(10.9)$ & 0.60 & {$[0.33,1.06]$} & $0.48^{* *}$ & {$[0.27,0.83]$} \\
\hline SSA migrant women & $353(27.0)$ & $1.47^{*}$ & {$[1.05,2.07]$} & 0.93 & {$[0.64,1.34]$} \\
\hline Non-SSA heterosexual men & $276(18.3)$ & 1.00 & {$[1.00,1.00]$} & 1.00 & {$[1.00,1.00]$} \\
\hline Non-SSA heterosexual women & $312(29.7)$ & $1.62 * *$ & {$[1.15,2.28]$} & 1.22 & {$[0.85,1.75]$} \\
\hline \multicolumn{6}{|l|}{ Age at time of survey } \\
\hline $25-34$ & $281(36.1)$ & $1.98 * * *$ & {$[1.48,2.65]$} & $1.71 * *$ & {$[1.23,2.38]$} \\
\hline $35-44$ & $637(26.7)$ & $1.47^{* *}$ & {$[1.12,1.92]$} & 1.31 & {$[0.99,1.73]$} \\
\hline $45-54$ & $783(28.1)$ & $1.54 * *$ & {$[1.19,2.00]$} & $1.41^{*}$ & {$[1.08,1.83]$} \\
\hline $55-65$ & $459(18.2)$ & 1.00 & {$[1.00,1.00]$} & 1.00 & {$[1.00,1.00]$} \\
\hline \multicolumn{6}{|l|}{ Household composition } \\
\hline Single & $1,305(30.2)$ & 1.00 & {$[1.00,1.00]$} & 1.00 & {$[1.00,1.00]$} \\
\hline Couple without children & $599(21.6)$ & $0.71 * *$ & {$[0.57,0.89]$} & 0.87 & {$[0.70,1.08]$} \\
\hline Couple with child(ren) & $256(21.2)$ & $0.70^{*}$ & {$[0.52,0.94]$} & 0.98 & {$[0.75,1.28]$} \\
\hline \multicolumn{6}{|l|}{ Socioeconomic variables } \\
\hline \multicolumn{6}{|l|}{ Educational attainment } \\
\hline Primary level & $284(19.7)$ & 0.76 & {$[0.55,1.04]$} & 0.78 & {$[0.58,1.05]$} \\
\hline Less than a high school diploma & $830(29.6)$ & 1.14 & {$[0.93,1.40]$} & 1.07 & {$[0.89,1.28]$} \\
\hline High school diploma & $366(26.7)$ & 1.03 & {$[0.80,1.32]$} & 0.95 & {$[0.76,1.21]$} \\
\hline More than a high school diploma & $680(26.0)$ & 1.00 & {$[1.00,1.00]$} & 1.00 & {$[1.00,1.00]$} \\
\hline \multicolumn{6}{|l|}{ Occupational status } \\
\hline Employed & $1,208(22.5)$ & 1.00 & {$[1.00,1.00]$} & 1.00 & {$[1.00,1.00]$} \\
\hline Unemployed & $283(40.7)$ & $1.81 * * *$ & {$[1.46,2.24]$} & $1.43^{* *}$ & {$[1.15,1.77]$} \\
\hline On disability, retired or inactive & $669(29.3)$ & $1.30 * *$ & {$[1.08,1.57]$} & 1.20 & {$[0.99,1.46]$} \\
\hline \multicolumn{6}{|l|}{ Material deprivation } \\
\hline Yes & $595(40.1)$ & $1.84 * * *$ & {$[1.54,2.20]$} & $1.69 * * *$ & {$[1.41,2.03]$} \\
\hline Non & $1,565(21.7)$ & 1.00 & {$[1.00,1.00]$} & 1.00 & {$[1.00,1.00]$} \\
\hline \multicolumn{6}{|l|}{ Social relations } \\
\hline \multicolumn{6}{|c|}{ Proportion of family and friends informed of HIV status } \\
\hline None & $208(25.6)$ & 1.23 & {$[0.91,1.68]$} & 1.04 & {$[0.78,1.39]$} \\
\hline Less than half & $615(20.0)$ & 1.00 & {$[1.00,1.00]$} & 1.00 & {$[1.00,1.00]$} \\
\hline More than half & $453(31.2)$ & $1.50 * * *$ & {$[1.24,1.81]$} & $1.27^{*}$ & {$[1.05,1.54]$} \\
\hline All & $884(29.6)$ & $1.78^{* * *}$ & {$[1.42,2.23]$} & $1.50^{* *}$ & {$[1.17,1.92]$} \\
\hline \multicolumn{6}{|c|}{ Participation in AIDS association activities or activist } \\
\hline Yes & $326(32.9)$ & $1.29 *$ & {$[1.05,1.59]$} & 1.01 & {$[0.82,1.24]$} \\
\hline No & $1,834(25.5)$ & 1.00 & {$[1.00,1.00]$} & 1.00 & {$[1.00,1.00]$} \\
\hline \multicolumn{6}{|l|}{ Discrimination } \\
\hline Yes, on the basis of HIV & 304 (43.9) & $2.29 * * *$ & {$[1.86,2.81]$} & $1.75^{* * *}$ & {$[1.41,2.18]$} \\
\hline Yes, on some other basis & $596(34.8)$ & $1.82^{* * *}$ & {$[1.49,2.22]$} & $1.74 * * *$ & {$[1.45,2.09]$} \\
\hline No discrimination & $1,260(19.2)$ & 1.00 & {$[1.00,1.00]$} & 1.00 & {$[1.00,1.00]$} \\
\hline \multicolumn{6}{|l|}{ Comorbidities } \\
\hline Recent cancer ( $<5$ years) & & & & & \\
\hline Yes & $92(38.6)$ & 1.27 & {$[0.97,1.66]$} & 1.32 & {$[1.00,1.76]$} \\
\hline No & $2,068(26.2)$ & 1.00 & {$[1.00,1.00]$} & 1.00 & {$[1.00,1.00]$} \\
\hline Chronic hepatitis B & & & & & \\
\hline Yes & $100(24.6)$ & 0.92 & {$[0.61,1.40]$} & & \\
\hline No & $2,060(26.7)$ & 1.00 & {$[1.00,1.00]$} & & \\
\hline Untreated hepatitis C (vs. no hepatitis & & & & & \\
\hline Yes & $93(41.4)$ & $1.59 * *$ & {$[1.14,2.22]$} & $1.60 * *$ & {$[1.16,2.20]$} \\
\hline No & $2,067(26.0)$ & 1.00 & {$[1.00,1.00]$} & 1.00 & {$[1.00,1.00]$} \\
\hline Cardiovascular risk & & & & & \\
\hline Yes & $458(25.7)$ & 0.96 & {$[0.78,1.17]$} & & \\
\hline No & $1,702(26.9)$ & 1.00 & {$[1.00,1.00]$} & & \\
\hline
\end{tabular}




\begin{tabular}{llllll}
\hline \multicolumn{2}{l}{ HIV-related characteritics } & & & & \\
\hline $\begin{array}{l}\text { Period of HIV diagnosis } \\
\quad 2009\end{array}$ & $258(36.2)$ & 1.00 & {$[1.00,1.00]$} & 1.00 & {$[1.00,1.00]$} \\
$\quad 1997-2008$ & $1,058(24.4)$ & $0.67^{* *}$ & {$[0.51,0.89]$} & 0.76 & {$[0.58,1.01]$} \\
$\quad<1997$ & $844(27.1)$ & $0.75^{*}$ & {$[0.57,0.99]$} & 0.74 & {$[0.55,1.01]$} \\
On cART and viral load < 50 copies/mL & & & & & \\
$\quad$ Yes & $1,872(25.7)$ & $0.79^{*}$ & {$[0.63,0.99]$} & 0.94 & {$[0.75,1.17]$} \\
$\quad$ No & $288(32.4)$ & 1.00 & {$[1.00,1.00]$} & 1.00 & {$[1.00,1.00]$} \\
\hline
\end{tabular}

${ }^{1}$ Prevalence rate ratio (unadjusted).

${ }^{2}$ Prevalence rate ratio adjusted for socioepidemiological group, age, household composition, educational attainment, occupational status, material deprivation, proportion of family and friends informed of HIV status, participation in AIDS association activities or being an activist, discrimination, cancer, chronic hepatitis B, chronic hepatitis C, period of HIV-diagnosis and virological success.

Significance level: ${ }^{* * *} p<0.001, * * p<0.01, * p<0.05 . \mathrm{Cl}=$ Confidence interval.

MSM: Men who have sex with men, SSA: Sub-Saharan Africa. 


\section{APPENDIX}

The ANRS-Vespa2 Study Group includes France Lert (INSERM UMRS1018, France.Lert@inserm.fr) and Bruno Spire (INSERM UMRS912/ORS PACA), scientific coordinators; Patrizia Carrieri (INSERM UMR-S 912/ORS PACA), Rosemary Dray-Spira (INSERM UMRS1136), Christine Hamelin (INSERM UMRS1018), Nicolas Lorente (INSERM UMRS912/ORS PACA), Marie Préau (INSERM UMRS912/ORS PACA) and Marie Suzan-Monti (INSERM UMRS912/ORS PACA), with the collaboration of Marion Mora (INSERM UMRS912/ORS PACA).

\section{List of participating hospitals and investigators}

Aix-en-Provence, CH Pays d'Aix (T. Allègre, P. Mours, J.M. Riou, M. Sordage); Angers, CHU Hôtel-Dieu (J.M. Chennebault, P. Fialaire, V. Rabier); Annemasse, CH Alpes-Léman (M. Froidure, D. Huguet, D. Leduc); Avignon, Hôpital Henri Duffaut (G. Pichancourt, A. Wajsbrot); Besançon, Hôpital SaintJacques (C. Bourdeaux, A. Foltzer, B. Hoen, L. Hustache-Mathieu); Bobigny, Hôpital Avicenne (S. Abgrall, R. Barruet, O. Bouchaud, A. Chabrol, S. Mattioni, F. Mechai); Bondy, Hôpital Jean Verdier (V. Jeantils); Bordeaux, Hôpital Saint-André (N. Bernard, F. Bonnet, M. Hessamfar, D. Lacoste, D. Malvy, P. Mercié, P. Morlat, F. Paccalin, M.C. Pertusa, T. Pistone, M.C. Receveur, M.A. Vandenhende); Boulogne-Billancourt, Hôpital Ambroise Paré (C. Dupont, A. Freire Maresca, J. Leporrier, E. Rouveix); Caen, Hôpital Clémenceau (S. Dargere, A. de la Blanchardière, A. Martin, V. Noyon, R. Verdon); CH de Chambéry (O. Rogeaux); Clermont-Ferrand, CHU Gabriel Montpied (J. Beytout, F. Gourdon, H. Laurichesse); Colombes, Hôpital Louis-Mourier (F. Meier, E. Mortier, A.M. Simonpoli); Creil, CH Laennec (F. Cordier); Créteil, CHIC (I. Delacroix, V. Garrait, B. Elharrar), Hôpital Henri Mondor (S. Dominguez, A.S. Lascaux, J.D. Lelièvre, Y. Levy, G. Melica); Dijon, Hôpital du Bocage (M. Buisson, L. Piroth, A. Waldner); Eaubonne, Hôpital Simone Veil (N. Gruat, A. Leprêtre); Garches, Hôpital Raymond-Poincaré (P. de Truchis, D. Le Du, J.Cl. Melchior); $\mathrm{CH}$ de Gonesse (R. Sehouane, D. Troisvallets); CHU de Grenoble (M. Blanc, I. Boccon-Gibod, A. Bosseray, J.P. Brion, F. Durand, P. Leclercq, F. Marion, P. Pavese); La Rochelle, Hôpital Saint- Louis (E. Brottier-Mancini, L. Faba, M. Roncato-Saberan); La Roche-sur-Yon, CHD Les Oudairies (O. Bollengier-Stragier, J.L. Esnault, S. Leautez-Nainville, P. Perré); CH de Lagny Marne-la-Vallée (E. Froguel, M. Nguessan, P. Simon); Le Chesnay, CH de Versailles (P. Colardelle, J. Doll, C. Godin-Collet, S. Roussin-Bretagne); Le KremlinBicêtre, Hôpital de Bicêtre (J.F. Delfraissy, M. Duracinsky, C. Goujard, D. Peretti, Y. Quertainmont); CH du Mans (J. Marionneau); Lens, CH Dr. Schaffner (E. Aissi, N. Van Grunderbeeck); Limoges, CHU Dupuytren (E. Denes, S. Ducroix-Roubertou, C. Genet, P. Weinbreck); Lyon, Hôpital de la Croix-Rousse (C. Augustin-Normand, A. Boibieux, L. Cotte, T. Ferry, J. Koffi, P. Miailhes, T. Perpoint, D. Peyramond, I. Schlienger); Hôpital Édouard-Herriot (J.M. Brunel, E. Carbonnel, P. Chiarello, J.M. Livrozet, D. Makhloufi); Marseille, Hôpital de la Conception (C. Dhiver, H. Husson, A. Madrid, I. Ravaux, M.L. de Severac, M. Thierry Mieg, C. Tomei), Hôpital Nord (S. Hakoun, J. Moreau, S. Mokhtari, M.J. Soavi), Hôpital Sainte Marguerite (O. Faucher, A. Ménard, M. Orticoni, I. Poizot-Martin, M.J. Soavi); Montpellier, Hôpital Gui de Chauliac (N. Atoui, V. Baillat, V. Faucherre, C. Favier, J.M. Jacquet, V. Le Moing, A. Makinson, R. Mansouri, C. Merle); Montivilliers, Hôpital Jacques Monod (N. Elforzli); Nantes, Hôtel-Dieu (C. Allavena, O. Aubry, M. Besnier, E. Billaud, B. Bonnet, S. Bouchez, D. Boutoille, C. Brunet, N. Feuillebois, M. Lefebvre, P. Morineau-Le Houssine, O. Mounoury, P. Point, F. Raffi, V. Reliquet, J.P. Talarmin); Nice, Hôpital I'Archet (C. Ceppi, E. Cua, P. Dellamonica, F. De SalvadorGuillouet, J. Durant, S. Ferrando, V. Mondain-Miton, I. Perbost, S. Pillet, B. Prouvost-Keller, C. Pradier, P. Pugliese, V. Rahelinirina, P.M. Roger, E. Rosenthal, F. Sanderson); Orléans, Hôpital de La Source (L. 
Hocqueloux, M. Niang, T. Prazuck), Hôpital Porte Madeleine (P. Arsac, M.F. Barrault-Anstett); Paris, Hôpital Bichat - Claude-Bernard (M. Ahouanto, E. Bouvet, G. Castanedo, C. Charlois-Ou, A. Dia Kotuba, Z. Eid-Antoun, C. Jestin, K. Jidar, V. Joly, M.A. Khuong-Josses, N. Landgraf, R. Landman, S. Lariven, A. Leprêtre, F. L'hériteau, M. Machado, S. Matheron, F. Michard, G. Morau, G. Pahlavan, B.C. Phung, M.H. Prévot, C. Rioux, P. Yéni), Hôpital Cochin-Tarnier (F. Bani-Sadr, A. Calboreanu, E. Chakvetadze, D. Salmon, B. Silbermann), Hôpital européen Georges-Pompidou (D. Batisse, M. Beumont, M. Buisson, P. Castiel, J. Derouineau, M. Eliaszewicz, G. Gonzalez, D. Jayle, M. Karmochkine, P. Kousignian, J. Pavie, I. Pierre, L. Weiss), Hôpital Lariboisière (E. Badsi, M. Bendenoun, J. Cervoni, M. Diemer, A. Durel, A. Rami, P. Sellier), Hôpital Pitié-Salpêtrière (H. Ait- Mohand, N. Amirat, M. Bonmarchand, F. Bourdillon, G. Breton, F. Caby, J.P. Grivois, C. Katlama, M. Kirstetter, L. Paris, F. Pichon, L. Roudière, L. Schneider, M.C. Samba, S. Seang, A. Simon, H. Stitou, R. Tubiana, M.A. Valantin), Hôpital Saint-Antoine (D. Bollens, J. Bottero, E. Bui, P. Campa, L. Fonquernie, S. Fournier, P.M. Girard, A. Goetschel, H.F. Guyon, K. Lacombe, F. Lallemand, B. Lefebvre, J.L. Maynard, M.C. Meyohas, Z. Ouazene, J. Pacanowski, O. Picard, G. Raguin, P. Roussard, M. Tourneur, J. Tredup, N. Valin); Hôpital Saint-Louis (S. Balkan, F. Clavel, N. Colin de Verdière, N. De Castro, V. de Lastours, S. Ferret, S. Gallien, V. Garrait, L. Gérard, J. Goguel, M. Lafaurie, C. Lascoux-Combe, J.M. Molina, E. Oksenhendler, J. Pavie, C. Pintado, D. Ponscarme, W. Rozenbaum, A. Scemla), Hôpital Tenon (P. Bonnard, L. Lassel, M.G. Lebrette, T. Lyavanc, P. Mariot, R. Missonnier, M. Ohayon, G. Pialoux, M.P. Treilhou, J.P. Vincensini); Hôtel-Dieu (J. Gilquin, B. Hadacek, L. Nait-Ighil, T.H. Nguyen, C. Pintado, A. Sobel, J.P. Viard, O. Zak Dit Zbar); Perpignan, Hôpital Saint-Jean (H. Aumaître, A. Eden, M. Ferreyra, F. Lopez, M. Medus, S. Neuville, M. Saada); Pontoise, CH René' Dubos (L. Blum); Quimper, Hôpital Laennec (P. Perfezou); Rennes, Hôpital de Pontchaillou (C. Arvieux, J.M. Chapplain, M. Revest, F. Souala, P. Tattevin); Rouen, Hôpital Charles-Nicolle (S. Bord, F. Borsa-Lebas, F. Caron, C. Chapuzet, Y. Debab, I. Gueit, M. Etienne, C. Fartoukh, K. Feltgen, C. Joly, S. Robaday-Voisin, P. Suel); Saint-Denis, CH Delafontaine (M.A. Khuong, J. Krausse, M. Poupard, G. Tran Van); Saint-Etienne, CHU Nord (C. Cazorla, F. Daoud, P. Fascia, A. Frésard, C. Guglielminotti, F. Lucht); Strasbourg, Nouvel hôpital civil (C. Bernard-Henry, C. Cheneau, J.M. Lang, E. de Mautort, M. P artisani, M. Priester, D. Rey); Suresnes, Hôpital Foch (C. Majerholc, D. Zucman); Toulon, CHI Chalucet (A. Assi, A. Lafeuillade), Hôpital SainteAnne (J.P. de Jaureguiberry, O. Gisserot); Toulouse, Hôpital de La Grave (C. Aquilina, F. Prevoteau du Clary), Hôpital Purpan (M. Alvarez, M. Chauveau, L. Cuzin, P. Delobel, D. Garipuy, E. Labau, B. Marchou, P. Massip, M. Mularczyk, M. Obadia); Tourcoing, CH Gustave Dron (F. Ajana, C. Allienne, V. Baclet, X. de la Tribonnière, T. Huleux, H. Melliez, A. Meybeck, B. Riff, M. Valette, N. Viget); Tours, CHRU Bretonneau (F. Bastides, L. Bernard, G. Gras, P. Guadagnin); Vandoeuvre-lès-Nancy, CHU Brabois (T. May, C. Rabaud); Vannes, CH Bretagne Atlantique (A. Dos Santos, Y. Poinsignon); Villejuif, Hôpital Paul-Brousse, (O. Derradji, L. Escaut, E. Teicher, D. Vittecoq); CHI de Villeneuve-SaintGeorges, (J. Bantsima, P. Caraux-Paz, O. Patey). 